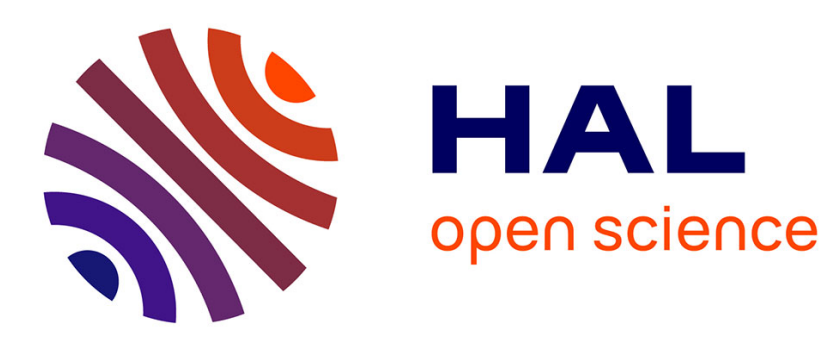

\title{
Estimation of nitrogen mineralization in the field from an incubation test and from soil analysis
}

\author{
Jean-Emmanuel Delphin
}

\section{To cite this version:}

Jean-Emmanuel Delphin. Estimation of nitrogen mineralization in the field from an incubation test and from soil analysis. Agronomie, 2000, 20 (4), pp.349-361. 10.1051/agro:2000132 . hal-00886050

\section{HAL Id: hal-00886050 \\ https://hal.science/hal-00886050}

Submitted on 1 Jan 2000

HAL is a multi-disciplinary open access archive for the deposit and dissemination of scientific research documents, whether they are published or not. The documents may come from teaching and research institutions in France or abroad, or from public or private research centers.
L'archive ouverte pluridisciplinaire HAL, est destinée au dépôt et à la diffusion de documents scientifiques de niveau recherche, publiés ou non, émanant des établissements d'enseignement et de recherche français ou étrangers, des laboratoires publics ou privés. 


\title{
Estimation of nitrogen mineralization in the field from an incubation test and from soil analysis
}

\author{
Jean-Emmanuel DeLPHIN* \\ Unité de Recherches Vigne et Vin, INRA, 28 rue de Herrlisheim, 68021 Colmar Cedex, France
}

(Received 9 August 1999; revised 9 March 2000; accepted 21 March 2000)

\begin{abstract}
An incubation test without leaching and a statistical model based on soil properties were used to predict the amount of $\mathrm{N}$ mineralized under maize. The results were compared with net $\mathrm{N}$ mineralization estimated by calculating the $\mathrm{N}$ balance sheet in the field. The field experiments were conducted over three years on ten sites covering various soil types in the North-East of France. Each year, one part of each of the soil samples collected on the different sites was incubated at constant water content $\left(90 \%\right.$ of the water content at $0.1 \mathrm{MPa}$ matrix suction) and at $20^{\circ} \mathrm{C}$. The other part was incubated under outdoor conditions during maize growth. According to the soil type, the amount of $\mathrm{N}$ mineralized at $20{ }^{\circ} \mathrm{C}$ over 275 days ranged between 33 and $93 \mathrm{mg} \cdot \mathrm{kg}^{-1}$, with a mean coefficient of variation of $10 \%$. These amounts, adjusted for soil temperature, were in good agreement with the values measured by outdoor incubation. The net $\mathrm{N}$ mineralization predicted from soil characteristics was less than that measured by laboratory incubation, particularly in organic soils. Methods used to measure net $\mathrm{N}$ mineralization in the field were sometimes unreliable. These results were ascribed to the poor precision of the measurements (mean CV $=29 \%$ ) and to the occurrence of uncontrolled $\mathrm{N}$ losses in the field, particularly nitrate leaching and diffusion. In these situations (5 out of 15), the amounts of $\mathrm{N}$ mineralized in the field were found to be distinctly lower than the predictions from incubation. In the other situations, taking into account the imprecision of in situ measurements (mean CV $=19 \%$ ), the incubation tests appeared to predict $\mathrm{N}$ mineralization in the field correctly. The statistical model was not satisfactory for predicting net $\mathrm{N}$ mineralization in the field. More reliable field methods will be needed to improve the agreement between these two approaches to estimating $\mathrm{N}$ mineralization.
\end{abstract}

\section{N-mineralization / incubation test / field experiment/ soil analysis / maize}

Résumé - Estimation de la minéralisation de l'azote au champ à partir d'un test d'incubation et de données de l'analyse de terre. La fourniture d'azote minéral par le sol est estimée à partir d'un test d'incubation sans lessivage et sur la base d'un calcul portant sur certaines caractéristiques du sol. Ces résultats sont comparés à la minéralisation nette estimée au champ par le calcul du bilan de l'azote au cours d'une culture de maïs. Les essais sont conduits sur 3 années et concernent 10 sites représentatifs de la diversité des sols de la Plaine d'Alsace. Pour chaque site, chaque année, le test

Communicated by Emmanuel Frossard (Lindau, Switzerland)

* Correspondence and reprints

delphin@colmar.inra.fr 
d'incubation est conduit en conditions contrôlées $\left(20{ }^{\circ} \mathrm{C}\right.$ et humidité constante) sur 275 jours et en conditions de températures extérieures durant la culture du maïs. La minéralisation à $20^{\circ} \mathrm{C}$ varie, selon le type de sol, de 33 à $93 \mathrm{mg} \cdot \mathrm{N} \cdot \mathrm{kg}^{-1}$ avec un coefficient de variation de l'ordre de $10 \%$. Ces résultats corrigés de l'effet température sont comparables à ceux obtenus en conditions extérieures. Les prévisions de minéralisation nette à partir des caractéristiques des sols sont inférieures aux valeurs obtenues par les tests d'incubation, surtout pour les sols organiques. Le bilan de l'azote au champ donne dans certaines situations des résultats peu fiables, du fait d'une précision médiocre des estimations $(\mathrm{CV}=$ $29 \%$ ) et de pertes d'azote par lessivage ou par diffusion. Dans 5 cas sur 15, vraisemblablement du fait de pertes d'azote minéral au champ, les mesures sur le terrain sont nettement inférieures aux prévisions obtenues à partir des résultats d'incubation. En dehors de ces cas, l'estimation de la minéralisation nette au champ par la méthode du bilan de l'azote est en accord avec les prévisions établies à partir des tests d'incubation, mais la précision des résultats reste faible (CV $=19 \%$ ). L'estimation à partir des caractéristiques des sols n'est pas satisfaisante. Une comparaison plus poussée dans le futur des deux approches de l'évaluation de la minéralisation nette au champ présentées ici passe par une meilleure maîtrise des mesures in situ.

\section{Minéralisation N / test d'incubation / expérimentation au champ / analyse de terre / maïs}

\section{Introduction}

Improvement in $\mathrm{N}$ fertilizer recommendations for crops is essential to reduce nitrate accumulation in the soil and the subsequent risk of contamination of water resources. Methods for optimizing $\mathrm{N}$ fertilizer rate in France are usually based on the calculation of a predictive balance sheet for mineral $\mathrm{N}$ in soil at the beginning and end of the crop season. Inorganic $\mathrm{N}$ derived from mineralization of soil organic matter is an important term of the $\mathrm{N}$ balance sheet [27, 33] particularly for summer crops without organic manure where soil organic matter is the main source of inorganic $\mathrm{N}$ supplied by the soil during the growing season.

It is widely recognized that incubation tests may be suitable for comparative estimates of potential mineralization in different soils; Stanford et al. [37] suggested that mineral $\mathrm{N}$ released in the field could be estimated from the kinetics of mineralization obtained under laboratory conditions. However, experiments have shown that $\mathrm{N}$ mineralization calculated from incubation tests involving leaching may overestimate the amounts of $\mathrm{N}$ mineralized in situ [5, 17, 35, 37]. Numerous procedures based on chemical extraction have been tested, but the results were not relevant to the amount of mineral $\mathrm{N}$ actually released by soil during incu- bation tests and field experiments [15]. Aerobic incubation without leaching has been used more recently for quantifying net $\mathrm{N}$ mineralization under controlled conditions $[22,28]$ but only a few studies have been performed to compare the results of aerobic incubation without leaching with those obtained by leaching methods or by direct mineralization measurements in the field [28].

Investigations have shown that the amount of inorganic $\mathrm{N}$ released by the humified organic matter during incubation tests without leaching is closely related to soil components, i.e. total $\mathrm{N}$, clay and carbonates, and can therefore be estimated from these soil characteristics using statistical models $[8,10]$. It may therefore be possible to predict soil $\mathrm{N}$ mineralization in the field from soil analyses performed for making fertilizer recommendations [24] or when mapping.

The objective of this study was to examine the possibility of using: i) incubation tests without leaching conducted at $20{ }^{\circ} \mathrm{C}$ and under outdoor conditions, and ii) a statistical model based on soil properties, to predict $\mathrm{N}$ mineralization in the field. Mineral N released by the soil's organic matter during maize growth was estimated from the amounts of $\mathrm{N}$ mineralized at $20{ }^{\circ} \mathrm{C}$, adjusted for soil temperature and compared with the estimate of $\mathrm{N}$ mineralization for the field made using $\mathrm{N}$ balance-sheets for the maize plots. 


\section{Materials and methods}

\subsection{Experimental sites}

The experiments were carried out on private farms on the Rhine plain in France from 1989 to 1991. Results of estimating N mineralization in the field have already been published [11, 12]; experimental conditions are briefly described here to assist comprehension. Experimental plots were established on 10 sites. The sites were selected for marked differences in soil texture and organic matter content and for their capacity for deep crop rooting in order to reduce the risk of nitrate leaching below the lowest soil layer sampled. The main soil characteristics of the sites are listed in Table I.

The study was conducted in 1989 on sites 1 to 6 , in 1990 on sites $1,2,5$ and 7 and in 1991 on sites $1,7,8,9$ and 10. All plots were plowed to a depth of $25-30 \mathrm{~cm}$. Grain maize (Zea mays) was grown on all sites; the previous crop was winter wheat
(Triticum aestivum) on sites 3 and 4 and maize on the others. The maize crop was sprinkler-irrigated, except for sites 1 and 2. Water was applied from mid-June till August: total amounts of irrigation ranged from 100 to $150 \mathrm{~mm}$, with $20-30 \mathrm{~mm}$ at each application. No organic manure was applied except residues of the previous crops. Figure 1 shows mean daily precipitation and soil temperature for the study area. The mean annual rainfall was 551,515 and $432 \mathrm{~mm}$ respectively in 1989 , 1990 and 1991.

Maize was sown at the end of April and harvested in mid-September. Initial inorganic $\mathrm{N}\left(\mathrm{NO}_{3}^{-}-\mathrm{N}\right.$ $+\mathrm{NH}_{4}^{+}-\mathrm{N}$ ) in the soil profile was estimated from samples collected a few days after the maize was sown, on two dates separated by 7-15 days. Each soil sample was obtained by mixing four separate cores for each $20 \mathrm{~cm}$ layer to $120 \mathrm{~cm}$ depth. Four independent samples were taken at each sampling date. Soil samples were stored at $-18{ }^{\circ} \mathrm{C}$ before analysis. Bulk density of the soil layers was measured using a gamma probe densitometer.

Table I. Characteristics and locations of selected soils $(0-20 \mathrm{~cm})$.

\begin{tabular}{|c|c|c|c|c|c|c|c|c|c|c|}
\hline $\begin{array}{c}\text { Site } n^{\circ} \\
\text { Location }\end{array}$ & $\begin{array}{c}1 \\
\text { Colmar } \\
\text { cambisol }^{\S}\end{array}$ & $\begin{array}{c}2 \\
\text { Epfig } \\
\text { cambisol }\end{array}$ & $\begin{array}{c}3 \\
\text { Dessenheim } \\
\text { fluvisol }\end{array}$ & $\begin{array}{c}4 \\
\text { Weckolsheim } \\
\text { fluvisol }\end{array}$ & $\begin{array}{c}5 \\
\text { Oberhergheim } \\
\text { fluvisol }\end{array}$ & $\begin{array}{c}6 \\
\text { Niederhergheim } \\
\text { fluvisol }\end{array}$ & $\begin{array}{c}7 \\
\text { Rustenhart } \\
\text { fluvisol }\end{array}$ & $\begin{array}{c}8 \\
\text { Illhauesern } \\
\text { fluvisol } g\end{array}$ & $\begin{array}{c}9 \\
\text { n Ostheim } \\
\text { gleyic fluviso }\end{array}$ & $\begin{array}{l}10 \\
\text { Rouffach } \\
\text { ol fluvisol }\end{array}$ \\
\hline Clay $\left(\mathrm{g} \cdot \mathrm{kg}^{-1}\right)$ & 225 & 221 & 257 & 240 & 230 & 287 & 241 & 451 & 435 & 323 \\
\hline Silt $\left(\mathrm{g} \cdot \mathrm{kg}^{-1}\right)$ & 659 & 667 & 381 & 405 & 394 & 278 & 400 & 390 & 468 & 409 \\
\hline Sand $\left(\mathrm{g} \cdot \mathrm{kg}^{-1}\right)$ & 95 & 91 & 343 & 335 & 360 & 412 & 338 & 110 & 48 & 247 \\
\hline $\begin{array}{l}\mathrm{CaCO}_{3} \\
\left(\mathrm{~g}^{\mathrm{kg}}{ }^{-1}\right)\end{array}$ & 160 & 0 & 187 & 274 & 0 & 0 & 118 & 17 & 0 & 0 \\
\hline $\begin{array}{l}\text { Organic C } \\
\left(\mathrm{g} \cdot \mathrm{kg}^{-1}\right)\end{array}$ & 12.1 & 12.4 & 11.4 & 11.2 & 9 & 12.9 & 12.3 & 29.3 & 29.1 & 12.4 \\
\hline $\begin{array}{l}\text { Total N } \\
\left(\mathrm{g} \cdot \mathrm{kg}^{-1}\right)\end{array}$ & 1.33 & 1.4 & 1.32 & 1.28 & 1.02 & 1.39 & 1.39 & 3.27 & 3.23 & 1.45 \\
\hline $\mathrm{pH}\left[\mathrm{H}_{2} \mathrm{O}\right]$ & 8.3 & 7.5 & 8.3 & 8.3 & 6.7 & 6.4 & 8.2 & 7.8 & 5.9 & 6.6 \\
\hline $\begin{array}{l}\text { Bulk density } \\
\left(\mathrm{g} \cdot \mathrm{cm}^{-3}\right)\end{array}$ & 1.3 & 1.5 & 1.4 & 1.4 & 1.5 & 1.4 & 1.4 & 1.0 & 1.0 & 1.2 \\
\hline $\begin{array}{l}\text { Field capacity } \\
\left(\mathrm{g} \cdot \mathrm{g}^{-1}\right)^{\#}\end{array}$ & 0.23 & 0.23 & 0.21 & 0.22 & 0.21 & 0.22 & 0.22 & 0.32 & 0.32 & 0.24 \\
\hline $\begin{array}{l}\text { Soil depth } \\
\text { (cm) }\end{array}$ & $>120$ & $>120$ & 100 & 100 & $>120$ & 80 & $>120$ & $>120 *$ & $>120^{*}$ & 100 \\
\hline
\end{tabular}

$\S$ FAO soil classification

\# water content at $0.1 \mathrm{MPa}$ matrix suction

* groundwater at $120-150 \mathrm{~cm}$ depth. 

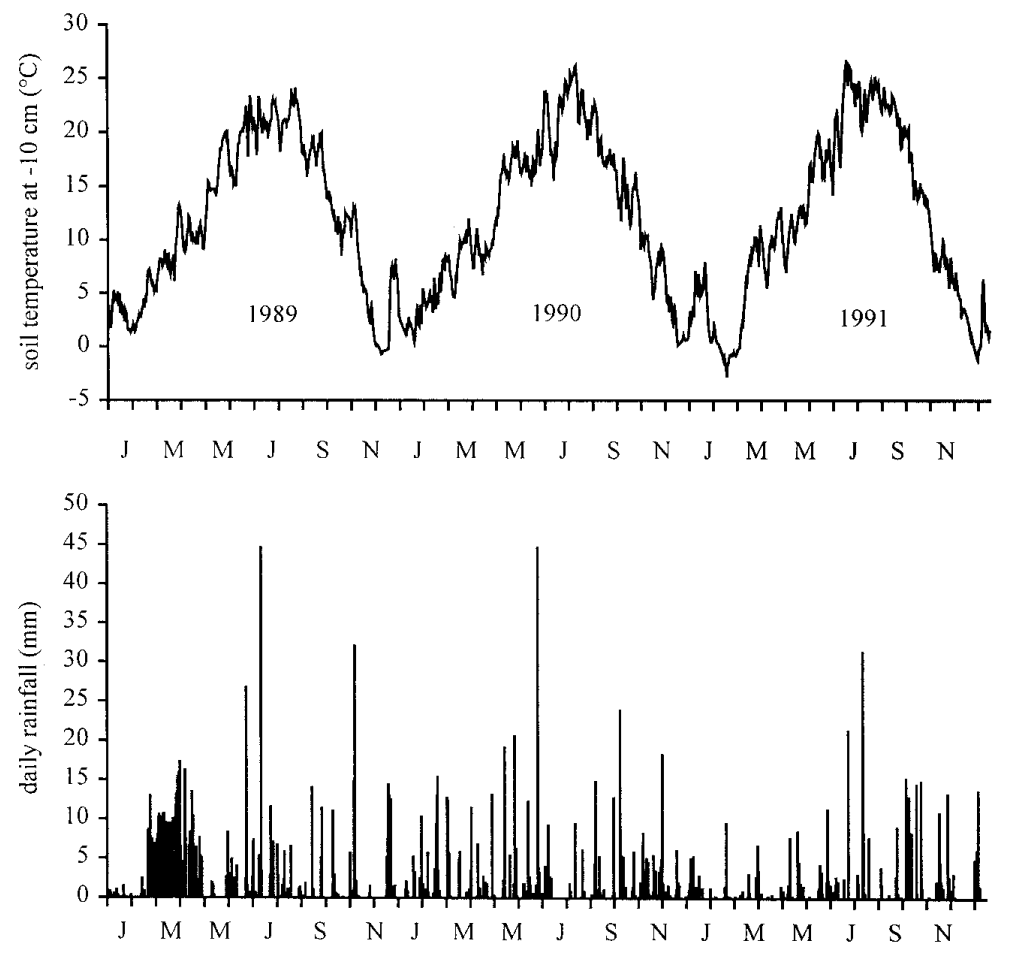

Figure 1. Daily soil temperature and rainfall at Colmar from 1989 to 1991.

\subsection{Net $\mathbf{N}$ mineralization measured in field experiments}

\subsubsection{Approach}

Soil $\mathrm{N}$ mineralization in the field during the maize growing season can be estimated using the following balance-sheet equation for $\mathrm{N}$ [27]:

$$
\mathrm{M}_{\mathrm{f}}=-\mathrm{N}_{\mathrm{f}}-\mathrm{N}_{\mathrm{i}}+\mathrm{N}_{\mathrm{e}}+\mathrm{N}_{\text {up }}-\mathrm{N}_{\text {input }}+\mathrm{N}_{\text {output }}
$$

where $\mathrm{M}_{\mathrm{f}}$ is the $\mathrm{N}$ mineralization of soil organic matter (in field conditions). $\mathrm{N}_{\mathrm{f}}$ is the fertilizer $\mathrm{N}$ input, $\mathrm{N}_{\mathrm{i}}$ and $\mathrm{N}_{\mathrm{e}}$ are the soil inorganic $\mathrm{N}$ at the beginning and end of the experiment respectively. $\mathrm{N}_{\text {up }}$ is the crop $\mathrm{N}$ uptake including the aboveground parts, the roots and the rhizodeposits of maize. $\mathrm{N}_{\text {input }}$ is the atmospheric deposition $\left(\mathrm{NH}_{4}^{+}\right.$, $\mathrm{NO}_{3}{ }^{-}$) and fixation by free-living bacteria, $\mathrm{N}_{\text {output }}$ is the $\mathrm{N}$ losses (leaching, erosion, and gaseous losses).

$\mathrm{N}$ in roots and rhizodeposits was not measured in this experiment, but Hétier et al. [20], found that they represented 22-24\% of the amount of $\mathrm{N}$ accumulated in the shoots. In this study, we assumed that the root/shoot ratio for $\mathrm{N}$ amount was 0.23 .

If we assume that $\mathrm{N}$ inputs were small and offset by $\mathrm{N}$ losses (leaching losses were presumed limited due to the soil and weather conditions encountered), $\mathrm{N}_{\text {input }}=\mathrm{N}_{\text {output }}$ and equation (1) becomes:

$$
\mathrm{M}_{\mathrm{f}}=-\mathrm{N}_{\mathrm{f}}-\mathrm{N}_{\mathrm{i}}+\mathrm{N}_{\mathrm{e}}+\mathrm{N}_{\mathrm{s}}+0.23 \mathrm{~N}_{\mathrm{s}}
$$

where $\mathrm{N}_{\mathrm{s}}$ is the amount of $\mathrm{N}$ in the shoots.

In the experiments presented here, no organic manure was applied and the residues of the previous crops were plowed in $4-5$ months before the beginning of the experiments. It is therefore assumed that the net effect of recent crop residues on soil $\mathrm{N}$ mineralization was small and that mineralization of the soil organic matter was the main source of inorganic $\mathrm{N}$.

Soil $\mathrm{N}$ mineralization in field conditions was estimated by three different methods: 


\subsubsection{In situ cylinder incubation}

Soil N mineralization was estimated in 1990 and 1991 by the $\mathrm{N}$ balance sheet using measurements on undisturbed soil enclosed in tubes under maize [31]. Galvanized iron tubes $(13 \mathrm{~cm}$ diameter, $65 \mathrm{~cm}$ long) were set up on each site in the middle of the interrow a few days after sowing the maize, using a compactor as described previously [11]. Each open tube was protected from precipitation by a loose cover allowing gas exchange. Four tubes were used to monitor soil moisture variation over time. The moisture content of the $0-40 \mathrm{~cm}$ soil layer was adjusted to $90 \%$ of the water content at $0.1 \mathrm{MPa}$ matrix suction by adding water once every month. The soil water content thus remained above $75 \%$ of the moisture at $0.1 \mathrm{MPa}$ matrix suction during the experiment. The experiment was conducted with 10 and 12 replicates respectively in 1990 and 1991. At harvest, soil samples were collected from the $0-20 \mathrm{~cm}, 20-40 \mathrm{~cm}$ and $40-60 \mathrm{~cm}$ layers of each tube for inorganic $\mathrm{N}$ determination. The amounts of $\mathrm{N}$ mineralized from soil organic matter were estimated using the following equation:

$$
\mathrm{M}_{\mathrm{f}}=-\mathrm{N}_{\mathrm{i}}+\mathrm{N}_{\mathrm{e}}
$$

\subsubsection{Maize receiving no $\mathrm{N}$ fertilizer}

This experiment was conducted in 1989 and 1991 on a $20 \mathrm{~m} \times 13 \mathrm{~m}$ plot. Nitrogen mineralized from soil was calculated from equation (2) with $\mathrm{N}_{\mathrm{f}}=0$. Dry matter and $\mathrm{N}$ content in the grain and above ground crop residues were determined at harvest. The estimation of dry matter production was made by sampling aerial parts on $10 \mathrm{~m}$ lengths of row with four replicates. Three representative plants were taken for total $\mathrm{N}$ analysis. The residual soil inorganic $\mathrm{N}\left(\mathrm{N}_{\mathrm{e}}\right)$ was estimated after the maize harvest, using the same procedure as for initial mineral $\mathrm{N}$ :

$$
\mathrm{M}_{\mathrm{f}}=-\mathrm{N}_{\mathrm{i}}+\mathrm{N}_{\mathrm{e}}+1.23 \mathrm{~N}_{\mathrm{s}}
$$

\subsubsection{Maize receiving ${ }^{15} \mathrm{~N}$ fertilizer}

${ }^{15} \mathrm{~N}$ experiments were carried out in 1990 and 1991. Unlabelled $\mathrm{N}$ fertilizer was applied as $\mathrm{KNO}_{3}$ on a $20 \mathrm{~m} \times 13 \mathrm{~m}$ plot, except for $1.6 \mathrm{~m} \times 1 \mathrm{~m}$ microplots receiving the same dressing but as $\mathrm{K}^{15} \mathrm{NO}_{3}$. Microplots were sprayed with one liter of ${ }^{15} \mathrm{~N}$ solution followed by one liter of water. In 1990, four microplots on each site received $78 \mathrm{~kg} \cdot \mathrm{N} \cdot \mathrm{ha}^{-1}\left(5.29\right.$ at.\% excess $\left.{ }^{15} \mathrm{~N}\right)$ applied half on 22 May and the other half on 12 June. Similarly, $80 \mathrm{~kg} \cdot \mathrm{N} \cdot \mathrm{ha}^{-1}\left(4.94\right.$ at.\% excess $\left.{ }^{15} \mathrm{~N}\right)$ were applied on 30 May and 19 June 1991 on five microplots per plot.

The dry matter production was estimated on the unlabelled part of the plot as in the $0 \mathrm{~N}$ maize experiment. Three plants in the middle of the microplots were collected for total $\mathrm{N}$ and ${ }^{15} \mathrm{~N}$ determination. Soil sampling was carried out on a $80 \mathrm{~cm} \times 50 \mathrm{~cm}$ rectangular area in the middle of the microplots on the same dates as plant sampling. For the $0-30 \mathrm{~cm}, 30-60 \mathrm{~cm}$ and $60-120 \mathrm{~cm}$ soil layers, 12, 6 and 3 cores were taken respectively, between and within the maize rows. Part of each soil sample was frozen until being analyzed for inorganic $\mathrm{N}$ (labeled and unlabeled), the remainder being air dried for total $\mathrm{N}$ determination.

The amounts of $\mathrm{N}$ released by soil organic matter were estimated using equation (4) applied to the non-fertilizer derived $\mathrm{N}$ :

$$
\mathrm{M}_{\mathrm{f}}=-\mathrm{N}_{\mathrm{i}}+\mathrm{N}_{\mathrm{es}}+1.23 \mathrm{~N}_{\mathrm{ss}}
$$

where $\mathrm{N}_{\mathrm{es}}$ is the inorganic $\mathrm{N}$ derived from the soil at the end of the experiment and $\mathrm{N}_{\mathrm{ss}}$ the amount of $\mathrm{N}$ derived from soil in the shoots. $\mathrm{N}_{\mathrm{es}}$ and $\mathrm{N}_{\mathrm{ss}}$ were calculated by deducting from labeled and unlabeled nitrogen the amounts derived from fertilizer. $\mathrm{N}$ derived from fertilizer was estimated on the base of the fertilizer ${ }^{15} \mathrm{~N}$ excess.

\subsection{Incubation tests}

Soil samples of about $30 \mathrm{~kg}$ were collected for the incubation tests. They were taken from the 0-20 cm layer at four places on the different sites each year before the beginning of the field experiment and kept at $5{ }^{\circ} \mathrm{C}$ until laboratory incubation. Coarse residues of the previous crop were discarded. 


\subsubsection{Incubation test at $20^{\circ} \mathrm{C}$}

An aerobic incubation test was conducted at $20 \pm 0.5^{\circ} \mathrm{C}$ on four jars in 1989 and on five jars in 1990 and $1991.1 .2 \mathrm{~kg}$ of the fresh soil sample, previously homogenized by hand, was put in a PVC jar (11.2 cm diameter, $13.0 \mathrm{~cm}$ length). In order to maintain soil moisture at $90 \%$ of water content at $0.1 \mathrm{MPa}$ matrix suction, the jars were weighed regularly and the lost water was made up. The soil water content remained above $80 \%$ of the moisture at $0.1 \mathrm{MPa}$ matrix suction during the experiment. After approximately 25, 120 and 200 days of incubation, the soil in one jar was removed for $\mathrm{NO}_{3}{ }^{-}-\mathrm{N}$ and $\mathrm{NH}_{4}{ }^{+}-\mathrm{N}$ determination; two more jars were removed after approximately 300 days. Some authors reported that pretreatment of soil before incubation may affect the initial $\mathrm{N}$ mineralization $[6,26]$. Though this effect seemed to be limited in our experimental conditions, the net $\mathrm{N}$ mineralization $\mathrm{M}_{\mathrm{il}}$ was calculated from the cumulative curves between 25 and 300 days of incubation (Fig. 2).

\subsubsection{Outdoor incubation test}

Another incubation test was conducted outdoors during the maize growing season. Three kilograms of fresh soil were homogenized by hand and placed in $30 \mathrm{~cm}$ long PVC jars installed upright in the soil
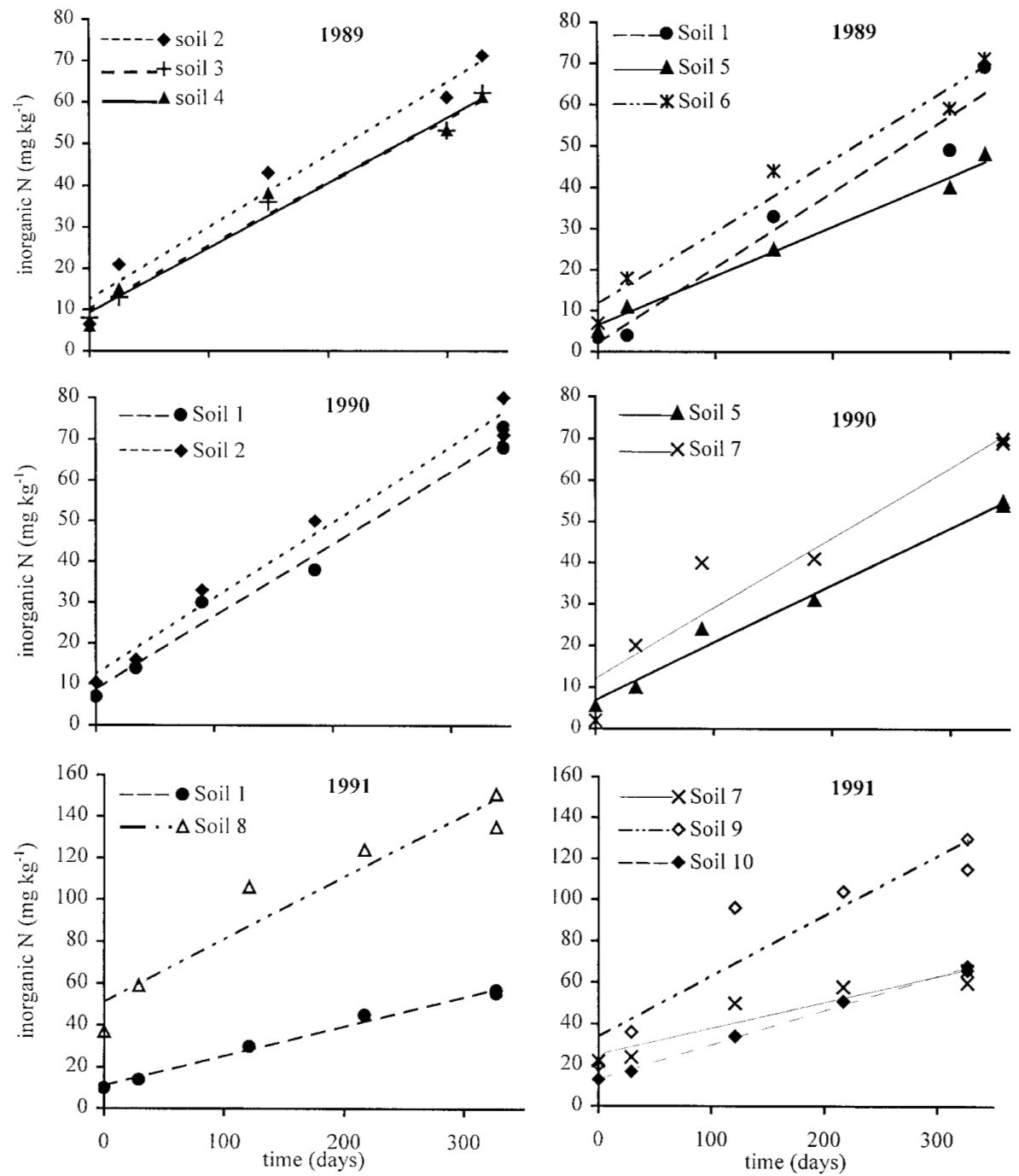

Figure 2. Inorganic $\mathrm{N}$ content of soils incubated at $20{ }^{\circ} \mathrm{C}$. 
near site 1 , with the open top above the soil surface. The jars were covered with a shield to keep out precipitation. The soil moisture was maintained between 80 and $90 \%$ of the water content at $0.1 \mathrm{MPa}$ matrix suction by weighing the jars every week. One jar was removed approximately 25, 50 and 100 days after the beginning of the experiment and two jars after 150 days of incubation (at the date of the maize harvest) for inorganic $\mathrm{N}$ determination. $\mathrm{N}$ accumulated in the jars over the incubation period was assumed to represent the net $\mathrm{N}$ mineralized under outdoor conditions $\left(\mathrm{M}_{\mathrm{io}}\right)$.

\subsection{Analytical procedures}

$\mathrm{NO}_{3}{ }^{-} \mathrm{N}$ and $\mathrm{NH}_{4}{ }^{+}-\mathrm{N}$ in soil were extracted with $1.0 \mathrm{~mol} \cdot \mathrm{L}^{-1} \mathrm{KCl}$ (soil/extractant ratio: $1 / 2$ ) and determined by colorimetry using a Technicon autoanalyser [21, 38]. Soil and plant total $\mathrm{N}$ were measured by the Kjeldahl method followed by colorimetric $\mathrm{NH}_{4}^{+} \mathrm{N}$ analysis. ${ }^{15} \mathrm{~N}$ excess of total $\mathrm{N}$ was measured at the Laon Agronomy Station using a mass spectrometer (VG SIRA 9) linked to a $\mathrm{CN}$ analyzer (NA 1500 Fisons Instruments). The ${ }^{15} \mathrm{~N}$ excess of inorganic soil $\mathrm{N}$ was determined on $\mathrm{NH}_{4}{ }^{+}$collected in $0.05 \mathrm{~mol} \cdot \mathrm{L}^{-1} \mathrm{H}_{2} \mathrm{SO}_{4}$ after reduction and steam distillation of the $\mathrm{KCl}$ extract.

\subsection{Prediction of net $\mathrm{N}$ mineralization}

Previous results obtained with 16 soils have shown that $\mathrm{N}$ mineralization estimated with a laboratory incubation test, similar to that used in this study, was closely related to soil components [10]. The following statistical regression, used in the present study, was found on a larger sample of 48 soils (unpublished results):

$$
\begin{gathered}
\mathrm{pM}_{\mathrm{il}}=42.8(\text { Ntot })^{0.53}-0.026 \text { Clay }-0.021 \text { Calc } \\
\left(\mathrm{r}^{2}=0.69\right)
\end{gathered}
$$

where $\mathrm{pM}_{\mathrm{i} 1}$ is the predicted $\mathrm{N}$ mineralization on a 25-300 d incubation period at $20{ }^{\circ} \mathrm{C}\left(\mathrm{mg} \cdot \mathrm{kg}^{-1}\right)$, Ntot is the Kjeldahl $\mathrm{N}$ content of soil $\left(\mathrm{g} \cdot \mathrm{kg}^{-1}\right)$, clay is the clay content $\left(\mathrm{g} \cdot \mathrm{kg}^{-1}\right)$ and calc is the total carbonate content $\left(\mathrm{g} \cdot \mathrm{kg}^{-1}\right)$.
In order to convert the amount of inorganic $\mathrm{N}$ released during incubation tests to the amount mineralized in the field, it was assumed that i) the plow layer is the main source of $\mathrm{N}$ mineralization, inorganic $\mathrm{N}$ released from the lower layers being ignored, ii) the net $\mathrm{N}$ mineralization at $20{ }^{\circ} \mathrm{C}$ follows a zero order kinetic and iii) the temperature effect on soil biological processes is described by a $\mathrm{Q}_{10}$ function.

The mean rate $\mathrm{r}$ and predicted mean rate pr of $\mathrm{N}$ mineralization $\left(\mathrm{mg} \cdot \mathrm{kg}^{-1} \cdot \mathrm{d}^{-1}\right)$ were deduced from the net $\mathrm{N}$ mineralization $\left(\mathrm{M}_{\mathrm{il}}\right.$ or $\left.\mathrm{pM}_{\mathrm{il}}\right)$ obtained at $20{ }^{\circ} \mathrm{C}$ :

$$
\mathrm{r}=\mathrm{M}_{\mathrm{il}} / 275 \text { or } \mathrm{pr}=\mathrm{pM}_{\mathrm{il}} / 275 .
$$

The predicted amounts of $\mathrm{N}$ mineralized under outdoor conditions $\left(\mathrm{pM}_{\mathrm{io}}\right)$ were calculated as follows:

$$
\begin{gathered}
\mathrm{pM}_{\mathrm{io}}=\mathrm{r} \sum_{\mathrm{j}=1}^{\mathrm{n}} \mathrm{Q}_{10}\left(\left(\mathrm{~T}_{\mathrm{j}}-20\right) / 10\right) \\
\operatorname{orpM}_{\mathrm{io}}=\operatorname{pr} \sum_{\mathrm{j}=1}^{\mathrm{n}} \mathrm{Q}_{10}\left(\left(\mathrm{~T}_{\mathrm{j}}-20\right) / 10\right)
\end{gathered}
$$

where $\mathrm{Q}_{10}$ is the temperature coefficient, $\mathrm{T}_{\mathrm{j}}$ the mean daily soil temperature $\left({ }^{\circ} \mathrm{C}\right)$ at $10 \mathrm{~cm}$ depth recorded at the Colmar weather station on day $\mathrm{j}$, and $n$ the duration of the outdoor experiment (days).

The predicted amounts of $\mathrm{N}$ mineralized in the field on the different sites $\left(\mathrm{pM}_{\mathrm{f}}\right)$ were estimated from the outdoor incubation data by taking into account the bulk density and the mean depth of the arable layer $(27.5 \mathrm{~cm}$ for all plots).

\section{Results and discussion}

\subsection{Incubation tests}

The amounts of inorganic $\mathrm{N}$ released by the soil during incubation are shown in Table II. The net $\mathrm{N}$ mineralization at $20{ }^{\circ} \mathrm{C}\left(\mathrm{M}_{\mathrm{il}}\right)$ varied considerably according to the soil. The amounts of $\mathrm{N}$ mineral- 
Table II. Amounts of $\mathrm{N}$ mineralized during incubation tests $\left(\mathrm{mg} \cdot \mathrm{kg}^{-1}\right.$ soil).

\begin{tabular}{lcccc}
\hline Year & Site & $\begin{array}{r}\text { observed } \\
\text { at } 20{ }^{\circ} \mathrm{C} \\
(275 \mathrm{~d})\end{array}$ & $\begin{array}{c}\text { predicted from } \\
\text { equation }(6) \\
(275 \mathrm{~d})\end{array}$ & $\begin{array}{c}\text { observed } \\
\text { outdoor } \\
(150 \mathrm{~d})\end{array}$ \\
\hline 1989 & 1 & 50 & 41 & 30 \\
& 2 & 45 & 46 & 24 \\
& 3 & 42 & 40 & 20 \\
& 4 & 40 & 36 & 17 \\
& 5 & 33 & 37 & 14 \\
1990 & 6 & 45 & 43 & 22 \\
& 1 & 52 & 41 & 26 \\
& 2 & 52 & 45 & 30 \\
& 5 & 39 & 37 & 20 \\
1991 & 7 & 54 & 42 & 30 \\
& 1 & 42 & 40 & 26 \\
& 7 & 40 & 43 & 25 \\
& 8 & 90 & 67 & 50 \\
& 9 & 93 & 68 & 53 \\
& 10 & 44 & 44 & 28 \\
\hline
\end{tabular}

ized over 275 days ranged between 33 and $93 \mathrm{mg} \cdot \mathrm{kg}^{-1}$ soil. As shown in Figure 2, the kinetics of net $\mathrm{N}$ mineralization at $20{ }^{\circ} \mathrm{C}$ were usually adequately described by a zero-order kinetic $(\mathrm{P}<0.01)$. The rate of net $\mathrm{N}$ mineralization $(\mathrm{r})$ deduced from the slope of the linear regression of $\mathrm{N}$ mineralization versus time ranged from 0.12 to $0.34 \mathrm{mg} \cdot \mathrm{N} \cdot \mathrm{kg}^{-1} \cdot \mathrm{day}^{-1}$. The values of $\mathrm{r}$ observed were slightly higher than those obtained by Houot et al. [22] on a loamy soil and similar to the mineralization rates determined on loamy and chalky agricultural soils by Muller and Rémy [29] when using a $\mathrm{Q}_{10}$ of 2.5 to adjust their rates to $20{ }^{\circ} \mathrm{C}$. If one takes the $\mathrm{CV}$ of $\mathrm{r}$ as an estimate of the $\mathrm{CV}$ of the corresponding net $\mathrm{N}$ mineralization at $20{ }^{\circ} \mathrm{C}$, the mean $\mathrm{CV}$ of all the $\mathrm{M}_{\mathrm{il}}$ values was $9.9 \%$. A similar mean CV (10.8\%) was calculated for the results of the incubation tests replicated once or twice for the same soils collected on the same plot in different years (sites 1, 2, 5 and 7). Since there was no change in cropping practices during the experimental period on each site, the variability could mainly be attributed to spatial variation of the soil samples collected in the field and to the difficulty in obtaining homogeneous soil samples before incubation experiments and mineral $\mathrm{N}$ analysis.

The net $\mathrm{N}$ mineralization predicted from soil characteristics (Eq. (6)) was less than the actual amounts of $\mathrm{N}$ released during the incubation test at $20{ }^{\circ} \mathrm{C}$. The mean difference between the $15 \mathrm{M}_{\mathrm{il}}$ and $\mathrm{pM}_{\mathrm{il}}$ pairs $\left(5.6 \mathrm{mg} \cdot \mathrm{N} \cdot \mathrm{kg}^{-1}\right)$ was greater than zero $(P=0.02)$. In view of the coefficient of determination of equation (6), the differences could be partly explained by inadequacy of the statistical model, especially for soils 8 and 9 with high organic matter content (Tab. II). The discrepancy between predicted and measured values could be due to the use of total $\mathrm{N}$ as an indicator of mineralizable $\mathrm{N}$, whereas the distribution of the amount of organic $\mathrm{C}$ and $\mathrm{N}$ between labile and stable pools varies between sites according to the nature of the soil and management practices $[3,16]$. Differences in the distribution of organic matter between its various fractions were partly taken into account in equation (6) by the curvilinear relationship between the predicted $\mathrm{N}$ mineralization and the total $\mathrm{N}$ content, meaning that high organic matter content in cultivated soils is associated with a smaller labile fraction [7]. Nevertheless, differences in the amount of $\mathrm{N}$ released by soils with the same organic matter content can be partly attributed to differences in cropping intensity or crop rotation [30]. Several authors [19, 23, 39] have suggested that the light fraction of the soil organic matter might serve as an indicator of the more mineralizable pool.

\subsection{Comparison between laboratory and outdoor incubation}

For the 15 soil samples collected in 1989, 1990 and 1991, the net $\mathrm{N}$ mineralization in the outdoor incubations predicted by equation (7) $\left(\mathrm{pM}_{\mathrm{io}}\right)$ was in good agreement with the amounts of $\mathrm{N}$ mineralized under outdoor conditions $\left(\mathrm{M}_{\mathrm{io}}\right)$ (Fig. 3). The mean difference $\left(1.5 \mathrm{mg} \cdot \mathrm{N} \cdot \mathrm{kg}^{-1}\right.$ soil) represented $5.7 \%$ of the mean outdoor mineralization. These results suggest that temperature was the main factor responsible for the difference between the two incubation tests. Soil moisture was less influential, 


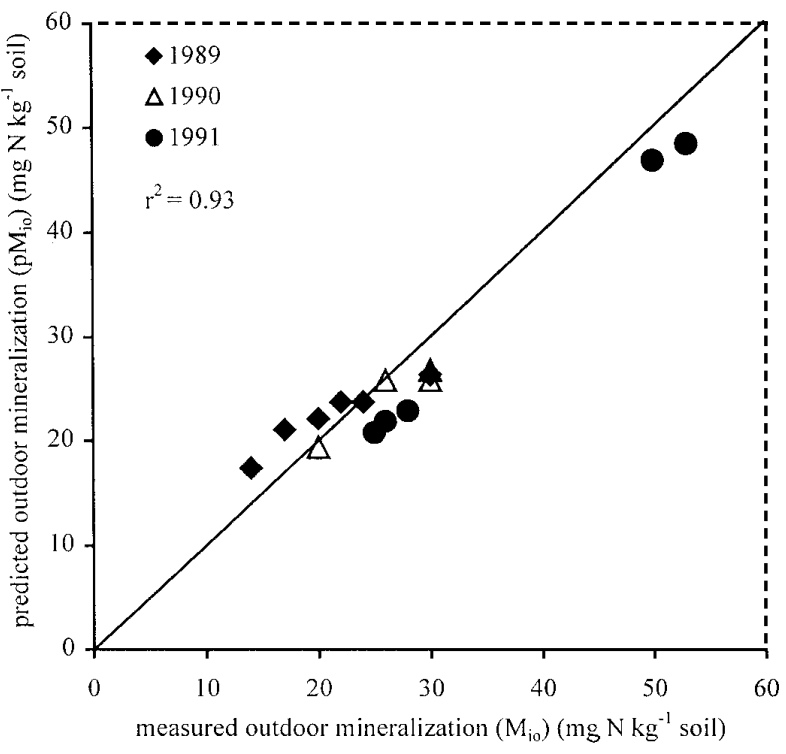

Figure 3. Relationship between measured values $\left(\mathrm{M}_{\mathrm{io}}\right)$ and those predicted by equation (7) $\left(\mathrm{pM}_{\mathrm{io}}\right)$ of outdoor $\mathrm{N}$ mineralization.

probably because it varied little and was similar in the two tests. These results also suggest that fitting $\mathrm{N}$ mineralization kinetics to a zero-order model and using a $\mathrm{Q}_{10}$ function $\left(\mathrm{Q}_{10}=2.5\right)$ to describe the temperature response are acceptable procedures in our experimental conditions.

The cumulative amounts of $\mathrm{N}$ mineralized during leaching incubations are usually fitted to a firstorder kinetic model but better fits are obtained with double exponential models [9]. However the more labile pool of mineralizable $\mathrm{N}$ determined in the latter case can be considered partly as an artifact due to soil treatment before incubation, particularly drying [5]. The use of exponential models to predict net $\mathrm{N}$ mineralization is often difficult because the two optimized parameters (mineralizable pool size and mineralization rate constant) are dependent on time [13]; it is thus not possible to assign any definite value to the kinetic parameters. Examples of fitting kinetic models to cumulative $\mathrm{N}$ mineralized in incubation tests without leaching are scarce; Addiscott [1] and Houot et al. [22] obtained good fits of net $\mathrm{N}$ mineralization to linear models. In our experiments, the constant rate of mineralization defined by the zero-order kinetic was estimated with satisfactory accuracy. It is thus possible to assign a definite value to this parameter, dependent on incubation conditions but not on time. It is certainly simplistic to assume that $\mathrm{N}$ mineralization is described by a zero-order kinetic and, for this reason, extrapolation should be limited to a time period similar to that of the experiments.

$\mathrm{Q}_{10}$ values calculated from the ratio of the mineralization rate at $20{ }^{\circ} \mathrm{C}$ and at $10{ }^{\circ} \mathrm{C}$ generally range between 2 and 3 [14, 34, 36]. In our experimental conditions, $\mathrm{N}$ mineralization prediction was not greatly affected by the temperature function because the mean temperature of the soil over the crop season was about $20{ }^{\circ} \mathrm{C}(18.6,18.9$ and $19.1^{\circ} \mathrm{C}$ in 1989,1990 and 1991 respectively). The difference between $\mathrm{N}$ mineralization estimated using equation (7) with $Q_{10}$ values of 3 and 2 was $-2 \%$ in $1989,0 \%$ in 1990 and $+3 \%$ in 1991 .

The amounts of $\mathrm{N}$ mineralized under outdoor conditions predicted by equation (8) were significantly less than observed (mean difference $=$ $4.1 \mathrm{mg} \cdot \mathrm{N} \cdot \mathrm{kg}^{-1}$ soil, significant at $\mathrm{P}=0.02$ ).

\section{3. $\mathrm{N}$ mineralization under field conditions}

Net $\mathrm{N}$ mineralization in field plots in 1989, 1990 and 1991 was estimated using equations (3-5). The results are presented in Table III. The mean standard deviation of the estimates was $23 \mathrm{~kg} \cdot \mathrm{N} \cdot \mathrm{ha}^{-1}$ $(\mathrm{CV}=29 \%)$. This variability was particularly related to the high CV observed on sites 2, 4 and 6 in 1989, and on 8 and 9 in 1991. When these data were excluded, the mean standard deviation of the $\mathrm{N}$ mineralization estimates on the remaining plots was $17 \mathrm{~kg} \cdot \mathrm{ha}^{-1}(\mathrm{CV}=19 \%)$, which is more than for the laboratory results obtained on the same soils.

These rather high coefficients of variation can be attributed to variability of the measurements of crop $\mathrm{N}$ uptake and, to a lesser extent, of the inorganic $\mathrm{N}$ measurements in the soil which were generally more accurate, except on sites 2, 8 and 9 [11].

The paired sample t-test showed no significant differences between the three methods used to estimate net $\mathrm{N}$ mineralization in the field. Nevertheless, owing to the high standard deviation 
Table III. Drainage, soil inorganic N amounts at the beginning of the maize crop and net $\mathrm{N}$ mineralization in the field estimated by the $\mathrm{N}$ balance-sheet method.

\begin{tabular}{|c|c|c|c|c|c|c|}
\hline \multirow[t]{2}{*}{ Year } & \multirow[t]{2}{*}{ Site } & \multirow{2}{*}{$\begin{array}{c}\text { Drainage }(\mathrm{mm}) \\
\text { before flowering* }\end{array}$} & \multirow{2}{*}{$\begin{array}{c}\text { Inorganic N } \\
\left(\mathrm{kg} \cdot \mathrm{ha}^{-1}\right)^{\#}\end{array}$} & \multicolumn{3}{|c|}{$\mathrm{N}$ mineralization under maize $\left(\mathrm{kg} \cdot \mathrm{ha}^{-1}\right)$} \\
\hline & & & & cylinder & No fertilizer plot ${ }^{\ddagger}$ & ${ }^{15} \mathrm{~N}$ plot ${ }^{\S}$ \\
\hline \multirow[t]{6}{*}{1989} & 1 & 0 & 8 & & $89(23)$ & \\
\hline & 2 & 11 & 19 & & $24(20)$ & \\
\hline & 3 & 6 & 5 & & $77(5)$ & \\
\hline & 4 & 18 & 26 & & $32(11)$ & \\
\hline & 5 & 27 & 10 & & $51(9)$ & \\
\hline & 6 & 42 & 20 & & $-17(6)$ & \\
\hline \multirow[t]{4}{*}{1990} & 1 & 3 & 4 & $119(7)$ & & $112(10)$ \\
\hline & 2 & 7 & 11 & $78(27)$ & & $109(34)$ \\
\hline & 5 & 6 & 4 & $83(25)$ & & $86(11)$ \\
\hline & 7 & 8 & 8 & $86(20)$ & & $106(23)$ \\
\hline \multirow[t]{5}{*}{1991} & 1 & 0 & 3 & $98(27)$ & $83(15)$ & $126(15)$ \\
\hline & 7 & 0 & 7 & $111(16)$ & $72(16)$ & $78(12)$ \\
\hline & 8 & 0 & 29 & $63(45)$ & $203(104)$ & $29(52)$ \\
\hline & 9 & 0 & 11 & $19(32)$ & $89(18)$ & $72(36)$ \\
\hline & 10 & 0 & 6 & $61(25)$ & $75(7)$ & 92 (17) \\
\hline
\end{tabular}

Standard deviations in parentheses

* Drainage estimated by STICS model [4]

\# Inorganic $\mathrm{N}$ amounts measured in the lowest $20 \mathrm{~cm}$ soil layer sampled at sowing

In situ cylinder incubation (Eq. (3))

${ }^{\ddagger}$ Maize receiving no $\mathrm{N}$ fertilizer (Eq. (4))

$\S^{\S}$ Maize receiving ${ }^{15} \mathrm{~N}$ fertilizer (Eq. (5)).

of the differences, one cannot conclude that these methods give similar results. The mean values of the three methods in 1991 and of the cylinder and ${ }^{15} \mathrm{~N}$ methods in 1990 were calculated to improve the estimates of net $\mathrm{N}$ mineralization in the field.

\subsection{Comparison between laboratory and field estimates}

The estimates of $\mathrm{N}$ mineralized in the field were lower than the values calculated from the incubation tests (Fig. 4). The mean differences of the estimates from field and incubation methods were significantly greater than zero. These results may be a consequence of the different conditions under which incubation tests and field experiments were carried out, which affect the rate of $\mathrm{N}$ transformation and the relative importance of the different processes involved in the fate of nitrogen in the soil.
Low mineralization rates in the field may be attributed to the water content of the arable soil layer, which was probably lower than the more optimal values maintained during incubation tests; the maize, however, was irrigated, except on sites 1 and 2. As soil moisture was not monitored in the field, it was not possible to adjust the amount of $\mathrm{N}$ mineralized during incubation for soil water content. The presence of plant roots in field conditions might enhance soil microbial activity, but there are still no methods to quantify their effect on $\mathrm{N}$ mineralization rate. The amount of $\mathrm{N}$ immobilized in roots, soil organic matter and microbial biomass during crop growth is difficult to estimate. Balabane and Balesdent [2] reported that $26 \%$ of the $\mathrm{N}$ applied as one mineral ${ }^{15} \mathrm{~N}$ fertilization was present as organic $\mathrm{N}$ in the soil at maize harvest; however, on maize cultivated with continuous ${ }^{15} \mathrm{~N}$ fertilization on a soil column, net immobilization represented only $14 \%$ of the amount applied [20]; on wheat the proportion ranged from 16 to $40 \%$ 


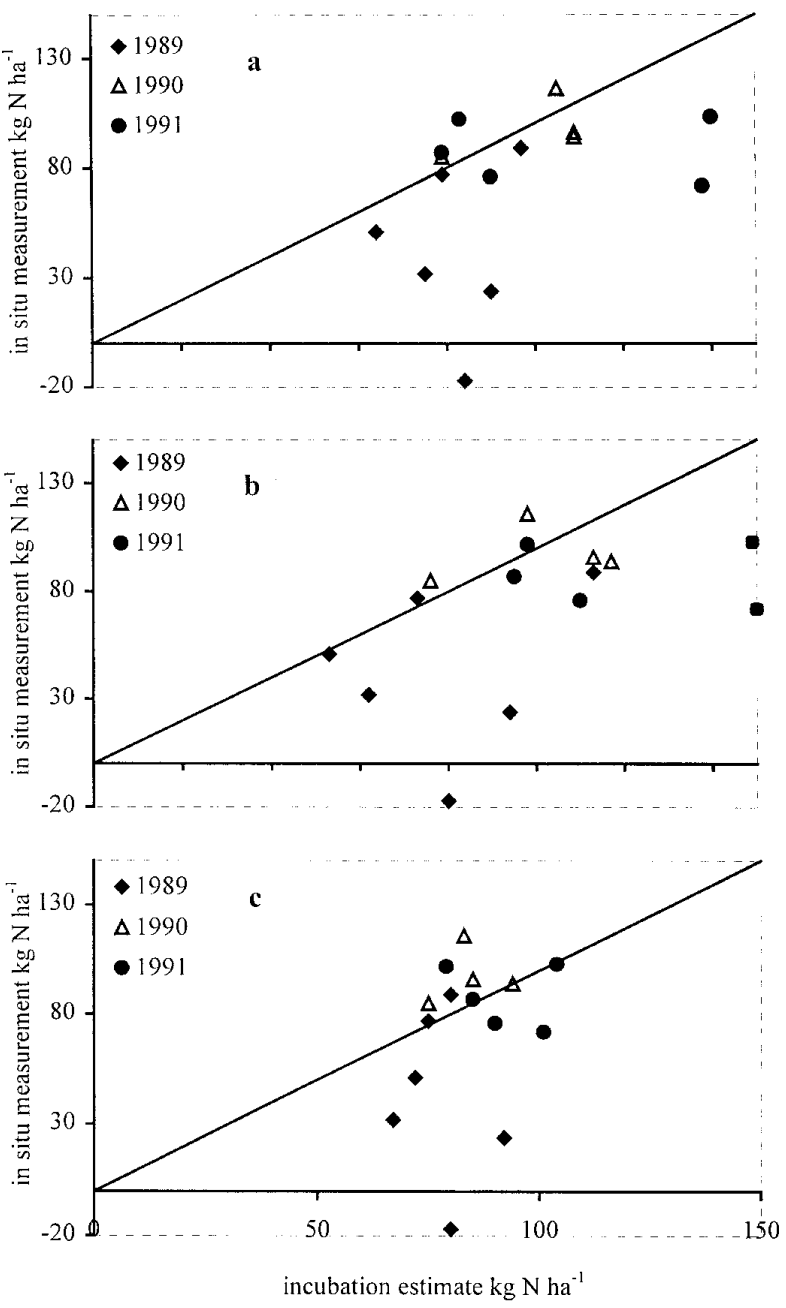

Figure 4. Relationship between field mineralization measured in situ and estimated from incubation tests a) at $20{ }^{\circ} \mathrm{C}, \mathrm{b}$ ) under outdoor conditions and c) predicted from equation (6).

and was dependent on the date and form of fertilizer application [32]. Net $\mathrm{N}$ immobilization during the decomposition of the residues of the previous crop was rather unlikely because their degradation (immobilization and subsequent mineralization) is generally rapid [25] in comparison with the interval between the harvest of the previous crop and the sowing of the following maize. $\mathrm{N}$ losses by denitrification could also be involved, however: only $5 \mathrm{~kg} \cdot \mathrm{N} \cdot \mathrm{ha}^{-1}$ of gaseous $\mathrm{N}$ fluxes were measured on site 8 during the cropping season by the acetylene inhibition method in 1991 [18] despite the large amount of organic matter in the soil. It is more likely that $\mathrm{N}$ losses were due to nitrate leaching at the beginning of the growing season, or else ion diffusion. Losses might be considerable on sites with a high mineral $\mathrm{N}$ content in the lower soil layers, particularly when drainage occurred at an early stage of growth (Tab. III) or when a water table was present near the soil surface (sites 8,9). In these cases, equation (2) used to estimate net $\mathrm{N}$ mineralization in the field is no longer valid.

When underestimated measurements in the field were excluded (sites 2, 4, 6 in 1989 and 8, 9 in 1991), the mean differences between the incubation $\left(\mathrm{M}_{\mathrm{il}}\right.$ and $\left.\mathrm{M}_{\mathrm{io}}\right)$ and field $\left(\mathrm{M}_{\mathrm{f}}\right)$ estimates of net $\mathrm{N}$ mineralization were not significant. The standard deviation of the differences was 12.3 and $16.7 \mathrm{~kg} \cdot \mathrm{N} \cdot \mathrm{ha}^{-1}$ for $\mathrm{M}_{\mathrm{il}}$ and $\mathrm{M}_{\mathrm{io}}$ respectively. $\mathrm{M}_{\mathrm{f}}$ was correlated with the incubation estimates $\mathrm{M}_{\mathrm{i} 1}$ $\left(\mathrm{r}^{2}=0.52, \mathrm{P}=0.02\right)$ and $\mathrm{M}_{\mathrm{i} 2}\left(\mathrm{r}^{2}=0.40, \mathrm{P}=0.05\right)$. Similarly no significant differences were observed between $\mathrm{M}_{\mathrm{f}}$ and the field $\mathrm{N}$ mineralization calculated using equation (8), but the correlation was not significant $\left(\mathrm{r}^{2}=0.17, \mathrm{P}=0.24\right)$. If $\mathrm{N}$ losses are assumed to be negligible, the results suggest that the effect of the difference in conditions between incubation and field experiments on $\mathrm{N}$ mineralization would have been at most of the same order of magnitude as the confidence interval for the mean difference of measurements (around $20 \mathrm{~kg} \cdot \mathrm{N} \cdot \mathrm{ha}^{-1}$ ). If, however, losses were significant, a stronger effect of experimental conditions on $\mathrm{N}$ mineralization would have been compensated for by $\mathrm{N}$ losses. For the sites excluded from the comparison, extrapolation of the incubation data probably gives a more realistic prediction of net $\mathrm{N}$ mineralization under field conditions than in situ measurements.

\section{Conclusions}

The quantification of $\mathrm{N}$ mineralization rates in the field from incubation tests presents many difficulties. On the one hand, methods of measuring $\mathrm{N}$ mineralization in the field are often rather unreliable because of the low precision of the results and the occurrence in some situations of uncontrolled $\mathrm{N}$ losses. On the other hand, there is some question 
about the similarity of the $\mathrm{N}$ transformation processes occurring in laboratory and field conditions. However, the difference in some environmental factors (temperature, soil moisture, leaching) between the field and laboratory in the present study was not great, while others (nitrate accumulation in the soil, plant root effect, temperature and moisture fluctuations) were substantial.

In 10 situations out of 15 where $\mathrm{N}$ losses were assumed to be negligible, the differences in environmental factors between incubation and field methods appear to have had no obvious effects on net $\mathrm{N}$ mineralization rate, taking into account the imprecision of field results. In the remaining 5 situations, $\mathrm{N}$ losses seemed to be an important cause of underestimation in the field.

The statistical model used here to predict $\mathrm{N}$ mineralization in the field was not satisfactory. It is important however to improve this approach, which requires little experimental labour, because of its value for agricultural use. A more accurate model is needed, perhaps with more suitable variables to predict soil $\mathrm{N}$ mineralization, particularly where organic matter content is high.

The ability of laboratory incubation to predict $\mathrm{N}$ mineralization in the field could be better evaluated if more reliable results were obtained in the field, particularly by improving $\mathrm{N}$ measurement in plants and soil, and by minimizing or estimating more accurately the experimental $\mathrm{N}$ losses.

Acknowledgements: Thanks go to Bruno Mary for helpful discussion and to Christiane Huck and C. Schneider for analyses and field assistance. This study was partly supported by the French "Ministère de la Recherche et de la Technologie" and the "Association Générale des Producteurs de Maïs".

\section{References}

[1] Addiscott T.M., Kinetics and temperature relationships of mineralization and nitrification in Rothamsted soils with differing histories, J. Soil Sci. 34 (1983) 343-353.

[2] Balabane M., Balesdent J., Input of fertilizerderived labelled $\mathrm{N}$ to soil organic matter during a grow- ing season of maize in the field, Soil Biol. Biochem. 24 (1992) 89-96.

[3] Balesdent J., Wagner G.H., Mariotti A., Soil organic matter turnover in long term field experiments as related by Carbon-13 natural abundance, Soil Sci. Soc. Am. J. 52 (1988) 118-124.

[4] Brisson N., Mary B., Ripoche D., Jeuffroy M.-H., Ruget F., Nicoulhaud B., Gate P., Devienne-Barret F., Antonioletti R., Durr C., Richard G., Beaudoin N., Recous S., Tayot X., Plenet D., Cellier P., Machet J.-M., Meynard J.-M., Delécolle R., STICS: a generic model for the simulation of crops and their water and nitrogen balances. I. Theory and parameterization applied to wheat and corn, Agronomie 18 (1998) 311-346.

[5] Cabrera M.L., Kissel D.E., Potentially mineralizable nitrogen in disturbed and undisturbed soil samples. Soil Sci. Soc. Am. J. 52 (1988) 1010-1015.

[6] Cabrera M.L., Kissel D.E., Evaluation of a method to predict nitrogen mineralized from soil organic matter under field conditions, Soil Sci. Soc. Am. J. 52 (1988) 1027-1031.

[7] Campbell C.A., Souster W., Loss of organic matter and potentially mineralizable nitrogen from Saskatchewan soils due to cropping, Can. J. Soil Sci. 62 (1982) 651-656.

[8] Chaussod R., Nicolardot B., Catroux G., Chrétien J., Relations entre les caractéristiques physico-chimiques et microbiologiques de quelques sols cultivés, Bull. Ass. Fr. Etud. Sols 2 (1986) 213-226.

[9] Deans J.R., Molina J.A.E., Clapp C.E., Models for predicting potentially mineralizable nitrogen and decomposition rate constants, Soil Sci. Soc. Am. J. 50 (1986) 323-326.

[10] Delphin J.E., Evaluation du pouvoir minéralisateur de sols agricoles en fonction de leurs caractéristiques physico-chimiques, Agronomie 6 (1986) 453-458.

[11] Delphin J.E., Gassmann B., Comparison of three methods for assessing mineral nitrogen released by soil under maize, Eur. J. Agron. 1 (1992) 221-226.

[12] Delphin J.E., Chapot J.Y., Schoellen A., Relations entre le pouvoir minéralisateur des sols et la minéralisation nette de l'azote au champ, Agronomie 11 (1991) 439-445.

[13] Dendooven L., Verstraeten L., Vlassak K., The $\mathrm{N}$-mineralization potential: an undefinable parameter, in: Mercks R., Verereecken H., Vlassak K. (Eds.), Fertilization and the Environment, Leuven University Press 1990, pp. 170-181. 
[14] Ellert B.H., Bettany J.R., Temperature dependence of net nitrogen and sulfur mineralization, Soil Sci. Soc. Am. J. 56 (1992) 1133-1141.

[15] Fox R.H., Piekielek W.P., Relationships among anaerobically mineralized nitrogen, chemical indexes, and nitrogen availability to corn, Soil Sci. Soc. Am. J. 48 (1984) 1087-1090.

[16] Franzluebbers A.J., Hons F.M., Zuberer D.A., Long term changes in soil carbon and nitrogen pools in wheat management systems, Soil Sci. Soc. Am. J. 58 (1994) 1639-1645.

[17] Fyles J.W., Fyles I.H., Feller M.C., Comparison of nitrogen mineralization in forest floor materials using aerobic and anaerobic incubation and bioassay techniques, Can. J. Soil Sci. 70 (1990) 73-81.

[18] Hack J., Schenck C., Delphin J.E., Nitrogen losses under maize cropping on a hydromorphic alluvial soil in the Rhine plain, in: Scaife A. (Ed.), Proc. 2nd Congress Eur. Soc. Agronomy 1992, pp. 258-259.

[19] Hassink J., Active organic matter fractions and microbial biomass as predictors of $\mathrm{N}$ mineralization, Eur. J. Agron. 3 (1994) 257-265.

[20] Hétier J.M., Andreux F., Schouller E., Marol C., Organic matter inputs to soil after growth of Carbon 14 Nitrogen 15 labeled maize, Soil Sci. Soc. Am. J. 50 (1986) 76-80.

[21] Henriksen A., Selmer-Olsen A.R., Automatic methods for determining nitrate and nitrite in water and soil extracts, Analyst 95 (1970) 514-518.

[22] Houot S., Molina J.A.E., Chaussod R., Clapp C.E., Simulation by NCSOIL of net mineralization in soils from the Dehérain and 36 parcelles fields at Grignon, Soil Sci. Soc. Am. J. 53 (1989) 451-455.

[23] Janzen H.H., Soil organic matter characteristics after long-term cropping to various spring wheat rotations, Can. J. Soil Sci. 67 (1987) 845-856.

[24] Machet J.-M., Dubrulle P., Louis P., Azobil: a computer programm for fertilizer $\mathrm{N}$ recommendations based on a predictive balance sheet method, in: Scaife A. (Ed.), Proc. First congress Eur. Soc. Agronomy, 1990, p. 21.

[25] Mary B., Recous S., Measurement of nitrogen mineralization and immobilization fluxes in soil as a means of predicting net mineralization, Eur. J. Agron. 3 (1994) 291-300.

[26] Mary B., Rémy J.-C., Essai d'appréciation de la capacité de minéralisation de l'azote des sols de grande culture I signification des cinétiques de minéralisation de la matière organique humifiée, Ann. Agron. 30 (1979) 513-527.
[27] Meisinger J.J., Evaluating plant-available nitrogen in soil-crop systems, in: Hauck R.D. (Ed.), ASACSSA-SSSA, Madison WI, Nitrogen in crop production, 1984, pp. 391-416.

[28] Menasseri S., Houot S., Chaussod R., Field test of biological and chemical methods for estimating soil nitrogen supply in a temperate climate, Eur. J. Agron. 3 (1994) 273-279.

[29] Muller J.C., Rémy J.C., Effet de l'azote minéral sur la cinétique de décomposition des pailles, in: Dutil P., Jacquin F. (Eds.), AISS-AFES-INRA, Proc. Colloque Humus-Azote, Reims, France, 1981, pp. 352-359.

[30] Powlson D.S., Brookes P.C., Christensen B.T., Measurement of soil microbial biomass provides an early indication of changes in total soil organic matter due to straw incorporation, Soil Biol. Biochem. 19 (1987) 159-164.

[31] Raison R.J., Connell M.J., Khanna P.K., Methodology for studying fluxes of soil mineral-N in situ, Soil Biol. Biochem. 19 (1987) 521-530.

[32] Recous S., Fresneau C., Faurie G., Mary B., The fate of labelled ${ }^{15} \mathrm{~N}$ urea and ammonium nitrate applied to a winter wheat crop. I. Nitrogen transformations in the soil, Plant Soil 112 (1988) 205-214.

[33] Rémy J.C., Hébert J., Le devenir des engrais azotés dans le sol, C. R. Acad. Agric. Fr. 163 (1977) 700-714.

[34] Ross D.J., Bridger B.A., Influence of temperature on biochemical processes in some soils from tussock grasslands. 2. Nitrogen mineralization, N. Z. J. Sci. 21 (1978) 591-597.

[35] Smith S.J., Young L.B., Miller G.E., Evaluation of soil nitrogen mineralization potentials under modified field conditions, Soil Sci. Soc. Am. J. 41 (1976) 74-76.

[36] Stanford G., Frere M.H., Schwaninger D.H., Temperature coefficient of soil nitrogen mineralization, Soil Sci. 115 (1973) 321-323.

[37] Stanford G., Carter J.N., Westermann D.T., Meisinger J.J., Residual nitrate and mineralizable soil nitrogen in relation to nitrogen uptake by irrigated sugarbeets, Soil Sci. Soc. Am. J. 69 (1977) 303-308.

[38] Verdow H., Ammonia determination based on indophenol formation with sodium salicylate, Water Res. 12 (1977) 399-402.

[39] Wander M.M., Traina S.J, Stinner B.R., Peters S.E., Organic and conventional management effects on biologically active soil organic matter pools, Soil Sci. Soc. Am. J. 58 (1994) 1130-1139. 